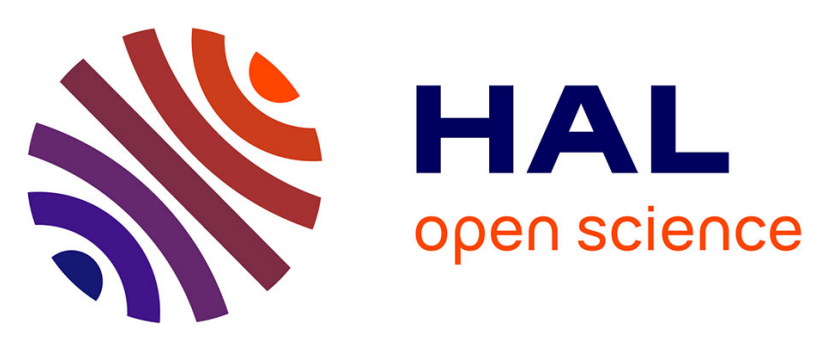

\title{
Arsenic Sorption on Chitosan-Based Sorbents: Comparison of the Effect of Molybdate and Tungstate Loading on As(V) Sorption Properties
}

\author{
Pamela Sierra-Trejo, Eric Guibal, José Louvier-Hernández
}

\section{To cite this version:}

Pamela Sierra-Trejo, Eric Guibal, José Louvier-Hernández. Arsenic Sorption on Chitosan-Based Sorbents: Comparison of the Effect of Molybdate and Tungstate Loading on As(V) Sorption Properties. Journal of Polymers and the Environment, 2020, 28, pp.934-947. 10.1007/s10924-020-01654-6 . hal02446613

\section{HAL Id: hal-02446613 \\ https://hal.mines-ales.fr/hal-02446613}

Submitted on 27 Jan 2020

HAL is a multi-disciplinary open access archive for the deposit and dissemination of scientific research documents, whether they are published or not. The documents may come from teaching and research institutions in France or abroad, or from public or private research centers.
L'archive ouverte pluridisciplinaire HAL, est destinée au dépôt et à la diffusion de documents scientifiques de niveau recherche, publiés ou non, émanant des établissements d'enseignement et de recherche français ou étrangers, des laboratoires publics ou privés. 


\title{
Arsenic Sorption on Chitosan-Based Sorbents: Comparison of the Effect of Molybdate and Tungstate Loading on As(V) Sorption Properties
}

\author{
Pamela V. Sierra-Trejo ${ }^{1}$ - Eric Guibal ${ }^{2}$. José F. Louvier-Hernández ${ }^{1}$ \\ José F. Louvier-Hernández \\ francisco.louvier@itcelaya.edu.mx \\ 1 Departamento de Ingeniería Química, Tecnológico Nacional \\ de México en Celaya, Celaya, Guanajuato, México \\ 2 C2MA, University of Montpellier, Alès cedex, France
}

\begin{abstract}
Modified chitosan gel beads, prepared by molybdate and tungstate coagulation methods, were tested for As(V) removal from solutions in the range of 5-200 $\mathrm{mg} \mathrm{As} \mathrm{L}^{-1}$. The sorbent is efficient at removing As(V) from acid solutions (optimum $\mathrm{pH}$ close to 3), the sorption capacities for As uptake in molybdate- and tungstate-loaded beads are 75 and $44 \mathrm{mg} \mathrm{As} \mathrm{g}^{-1}$ of dry mass, respectively. The mechanism of $\operatorname{As}(\mathrm{V})$ sorption is related to the ability of molybdate and tungstate ions to complex $\mathrm{As}(\mathrm{V})$ ions in acid solutions. As $(\mathrm{V})$ sorption process is mainly influenced by the presence of phosphate ions, but there is no influence of co-ions as nitrate and chloride. Arsenic desorption can be performed using phosphoric acid solutions. Arsenic adsorption proceeds in acidic solutions with a partial release of molybdate and tungstate and with residual concentrations of arsenic above the regulations for drinking water. For that reason, this material is a candidate for the treatment of industrial effluents.
\end{abstract}



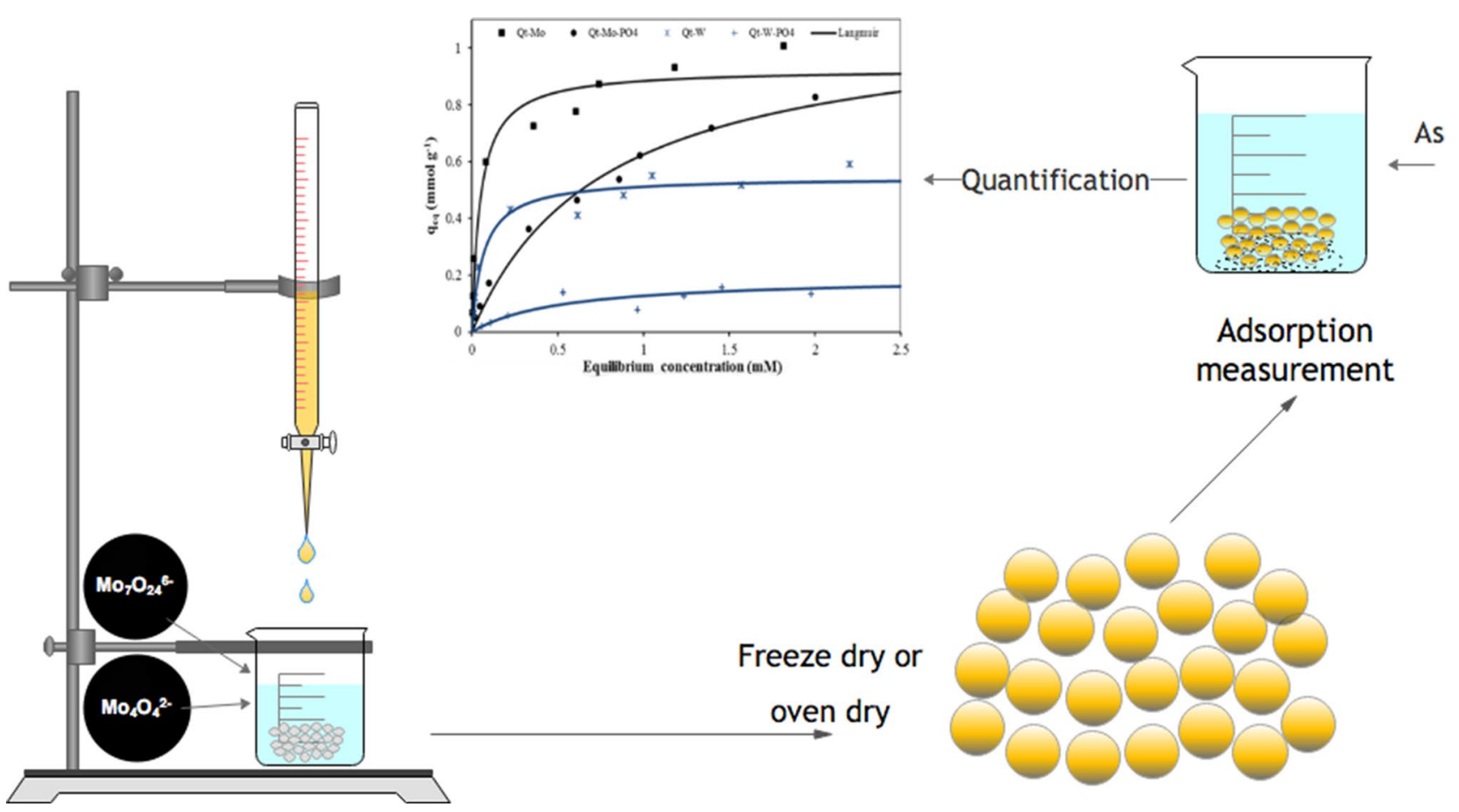

Adsorption measurement

Keywords Arsenic Treatment $\cdot$ Chitosan beads $\cdot$ Coagulation

\section{Introduction}

In the environment, arsenic exists in various forms. In natural waters, the two most common are arsenites $\left(\mathrm{AsO}_{3}\right)^{3-}$ and arsenates $\left(\mathrm{AsO}_{4}\right)^{3-}$, known as $\mathrm{As}(\mathrm{III})$ and $\mathrm{As}(\mathrm{V})$, respectively. Out of these, the trivalent form is more toxic and difficult to remove [1]. Although there is pollution by arsenic from anthropogenic sources, most of the arsenic present in groundwater has a geological origin mainly associated with an oxidation reaction of sulfide minerals in metasedimentary rocks [2]. In some countries (e.g., India, Bangladesh, and the United States) severe adverse health effects have been reported [3], because of arsenic naturally-occur in water for human consumption. Arsenic exposure from water and food associated with carcinogenic effects has been a growing concern in recent decades, as well as neurological, cardiovascular, respiratory, and liver damage, among others, skin, bladder, and lung cancer have been documented [4, 5]. Therefore, the presence of arsenic in natural waters is a global problem, and its removal is of vital importance.

The use of biomaterials for the treatment of water containing heavy metals has gained attention due to their simplicity and effectiveness, as well as their economic advantages [6]. Among the biosorbents used, chitosan (CTS) it is considered as an ideal candidate in the removal of heavy metals from wastewater, due to its amine groups that are strongly reactive with metal ions and are responsible for the uptake of metal cations by chelation. The amino groups easily protonate in acidic solutions that may cause electrostatic attraction of anionic compounds [7]. In addition to its chemical characteristics, chitosan has the advantage of being highly biocompatible and biodegradable [8]. However, although chitosan has been used successfully for the removal of metals such as $\mathrm{Cr}, \mathrm{Pb}$ and $\mathrm{Cu}$ [9-12] it has a significantly lower sorption capacity for $\mathrm{As}(\mathrm{V})$, which in most cases does not exceed $14 \mathrm{mg} \mathrm{As} \mathrm{g}^{-1}$ and it is even lower for As(III). In such a case, it is necessary to chemically modify the biopolymer to increase its sorption capacity by incorporating other functional groups with a strong affinity for the As. Molybdate can complex arsenate ions, thus modifying chitosan with molybdate may increase the arsenic sorption capacity of chitosan. There is a previous work that prepared biopolymer beads either impregnated with molybdate [13] or coagulated into a molybdate bath, that reached a removal capacity as high as $230 \mathrm{mg} \mathrm{As} \mathrm{g}^{-1} \mathrm{Mo}$ [14]. One objective of this work is to prepare smaller beads than those previously reported using an encapsulator.

Moreover, we are interested in preparing modified chitosan beads with tungstate since it is an ion that shares many chemical properties with molybdate. To our knowledge, 
there are no previous studies on arsenic sorption using chitosan modified with tungstate. The aqueous chemistry of tungsten compared with molybdate is an advantage because hexavalent tungsten form is very stable in most hydrothermal fluids [15]. For these reasons, in this work, we evaluate As(V) sorption capacity of CTS beads modified with either molybdate or tungstate using sorption isotherms and the effect of the drying process on sorption kinetics.

\section{Materials and Methods}

\section{Materials}

Chitosan medium molecular weight and deacetylation degree of $75 \%$ was purchase from Sigma Aldrich (Batch\# STBF3507V). Molecular weight was determined by measuring the intrinsic viscosity $\left(\mathrm{M}_{\mathrm{w}}=125,000 \mathrm{~g} \mathrm{~mol}^{-1}\right)$ using a Cannon-Fenske capillary tube with the Mark-Houwink constants proposed by Rinaudo in 2006 [16] to avoid aggregate formation [17]. Reagents (analytical grade): $\left(\mathrm{NH}_{4}\right)_{6} \mathrm{Mo}_{7} \mathrm{O}_{24} \cdot 4 \mathrm{H}_{2} \mathrm{O}$ and $\mathrm{Na}_{2} \mathrm{HAsO}_{4} \cdot 7 \mathrm{H}_{2} \mathrm{O}$ were purchased from Fluka AG and Merck respectively, and $\mathrm{Na}_{2} \mathrm{WO}_{4} \cdot 2 \mathrm{H}_{2} \mathrm{O}$ from Carlo Erba.

\section{Preparation of Molybdate-Loaded and Tungstate-Loaded Chitosan Beads (CTS- Mo and (TS-W)}

Chitosan $(1.5 \% \mathrm{w} / \mathrm{w})$ was dissolved in an acetic acid solution $(4 \% \mathrm{v} / \mathrm{v})$. The viscous solution was dropped using an encapsulator (BUCHI B-390) into ammonium heptamolybdate and sodium tungstate solutions at a concentration of $7 \mathrm{~g} \mathrm{~L}^{-1}$ of Mo and W, respectively. Coagulation is evaluated at three different $\mathrm{pH}$ values adjusting it with $\mathrm{HCl}$ and $\mathrm{NaOH}$. Beads remained in the coagulation bath for $24 \mathrm{~h}$ and were rinsed with distilled water until neutral $\mathrm{pH}$, then oven-dried at $50{ }^{\circ} \mathrm{C}$ until constant weight. Before carrying out the drying process, part of the beads was placed in a $0.1 \mathrm{M}$ phosphoric acid solution for $24 \mathrm{~h}$ to remove the labile part of the metal. For kinetic experiments, some beads were freeze-dried, some others were oven-dried, and the rest were kept hydrated.

\section{Characterization}

SEM-EDX SEM and SEM-EDX analysis were performed in oven-dried and freeze-dried beads, using an environmental scanning electron microscope Quanta FEG 200. The total concentration of Mo and $\mathrm{W}$ in the gel phase was determined using ICP-AES analysis (ICP-AES JY Activa M) by mineralization of the beads. For this purpose, we put $100 \mathrm{mg}$ of wet beads into a $50 \mathrm{~mL}$ beaker and added $3.0 \mathrm{~mL}$ of hydrogen peroxide $(30 \% \mathrm{v} / \mathrm{v})$ and $1.0 \mathrm{~mL}$ of nitric acid. The beaker was heated at $80{ }^{\circ} \mathrm{C}$ in a thermostated bath around 30 min until the beads dissolve completely. After cooling, the solution was transferred into a volumetric flask and averaged to $25 \mathrm{~mL}$, a sample of this solution was filtered through a Whatman filter membrane (pore size $1.2 \mu \mathrm{m}$ ) for ICP-AES analysis. The dry mass was obtained by weight loss at $50{ }^{\circ} \mathrm{C}$ for at least $72 \mathrm{~h}$. Experiments were run in triplicate.

Specific Surface Area (SSA) An analysis of the specific surface area was performed according to the standard gas adsorption method and the application of the BET equation [18], using nitrogen at $77 \mathrm{~K}$. The measurement was performed using a ChemBET TPR/TPD Chemisorption analyzer, with $50 \mathrm{mg}$ of sample for CTS-Mo and CTS-W beads, oven-dried, and freeze-dried. Before analysis, the samples were degassed for $5 \mathrm{~h}$ at $200{ }^{\circ} \mathrm{C}$, and the SSA of each sample was calculated using the single point method at a relative pressure $\left(\mathrm{P} / \mathrm{P}_{0}\right)$ of 0.2 .

FTIR Infrared analysis is carried out to clarify the interaction mechanism between Mo or W with chitosan and As(V). FTIR analysis was performed on CTS beads coagulated in a $\mathrm{NaOH}$ bath as well as on CTS-W and CTS-Mo beads coagulated by the ionotropic gelation method. The CTS-W and CTS-Mo beads were analyzed before and after arsenic sorption. For this procedure, a fraction of the corresponding oven-dried beads were ground and analyzed using an ATR accessory on a Thermo Scientific Nicolet iS5 from 4000 to $400 \mathrm{~cm}^{-1}$ with a resolution of $4 \mathrm{~cm}^{-1}$ and 25 scans.

\section{Arsenate Sorption and Desorption}

Previous studies determined that the optimum $\mathrm{pH}$ for arsenate sorption is around 3 [14]; this $\mathrm{pH}$ was fixed at the beginning of the process and was measured again at the end. For constructing the sorption isotherms, $20 \mathrm{mg}$ of oven-dried beads were put into a $20 \mathrm{~mL}$ of $\mathrm{As}(\mathrm{V})$ solution at different concentrations (from 5 to $200 \mathrm{mg} \mathrm{L}^{-1}$ ) at $20{ }^{\circ} \mathrm{C}$ for at least $96 \mathrm{~h}$. Subsequently, the concentration of As was measured by ICP-AES after filtering the sample through a Whatman filter membrane (pore size $1.2 \mu \mathrm{m}$ ). For kinetic studies, $400 \mathrm{mg}$ of beads (hydrated, oven-dried, and freeze-dried) were placed in $500 \mathrm{~mL}$ of $\mathrm{As}(\mathrm{V})$ solution, then samples of the solution were withdrawn at fixed times and filtered before analysis.

In this study, arsenic desorption is performed using phosphoric acid. As previous investigations have shown, phosphate solutions are efficient in arsenic removal [13]. For this purpose, $40 \mathrm{mg}$ of oven-dried beads of known arsenate concentration was brought into contact with $20 \mathrm{~mL}$ of eluent at a concentration of $0.1 \mathrm{M}$ for $24 \mathrm{~h}$. Concentrations of As, Mo, and $\mathrm{W}$ in solutions were determined by ICP-AES analysis. 


\section{Interference of Co-Ions and Competitor lons}

The effect of different ions on arsenic sorption is tested using phosphate, sulfate, nitrate, and chloride solutions prepared at molar ion:As ratios corresponding to $1: 1,10: 1$, and 100:1 with a sorbent dosage of $1.0 \mathrm{~g} \mathrm{~L}^{-1}$. Also, considering the actual composition of contaminated effluents [19, 20], solutions were prepared to reproduce these conditions and tested to evaluate the effect of different ions present during the sorption process. For these tests, the sorbent dosage is $1.25 \mathrm{~g} \mathrm{~L}^{-1}$.

\section{Results}

\section{Sorbent Manufacturing - Influence of the $\mathrm{pH}$ of the Coagulating Bath on Metal (Mo or W) Content}

Figure 1 shows the variation of the total Mo and W contents per gram of dry mass in the chitosan beads as a function of the initial $\mathrm{pH}$. For the initial tests, the $\mathrm{pH}$ was set at the beginning, and no considerable variation was observed due to the short time. However, in the manufacture of the subsequent batches, the $\mathrm{pH}$ was controlled during the process. The initial metal concentration in solution was set at $7 \mathrm{~g}$ $\mathrm{L}^{-1}$ for both molybdate and tungstate [14]. For molybdate, the maximum loading of $3.31 \mathrm{mmol}$ Mo per $\mathrm{g}$ of dry mass is reached at $\mathrm{pH} 6$, which is very close to the value at $\mathrm{pH}$ 5. According to the distribution diagram (Fig. SM1a of the supplementary material), calculated using Medusa software, the polynuclear hydrolyzed molybdate species present are $\mathrm{Mo}_{7} \mathrm{O}_{23}(\mathrm{OH})^{5-}$ and $\mathrm{Mo}_{7} \mathrm{O}_{24}{ }^{6-}$ in near-equivalent proportions. These two species represent more than $90 \%$ of the total molybdenum. The strong affinity of chitosan for molybdate has been directly correlated to the binding of CTS with this polynuclear polyhydrolized species [21]; this is consistent with a lower quantity of molybdate bound to chitosan at the

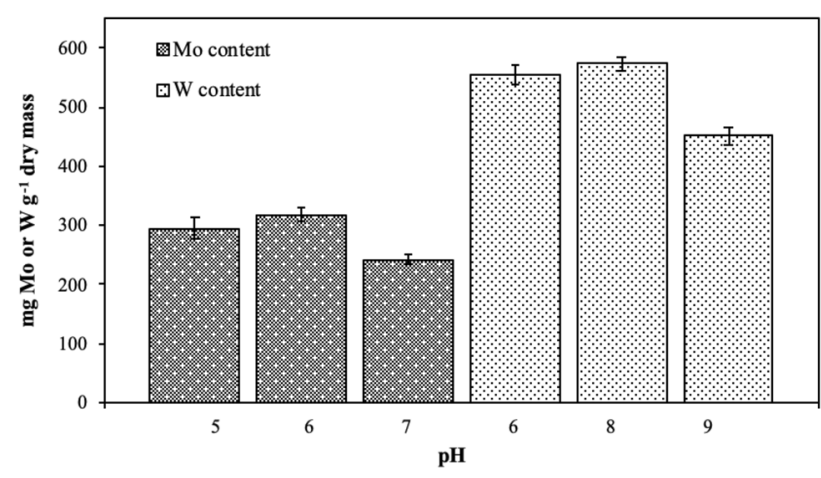

Fig. 1 Variation of the total amount of molybdate and tungstate in chitosan beads as a function of the initial $\mathrm{pH} . \mathrm{C}_{0}: 7 \mathrm{~g}$ Mo or $\mathrm{W} \mathrm{L}^{-1}$ initial $\mathrm{pH}$ near 7, which is $2.52 \mathrm{mmol} \mathrm{Mo}^{-1}$. The process allows incorporating comparable amounts of tungsten: at $\mathrm{pH} 8$, the $\mathrm{W}$ loading approaches $3.12 \mathrm{mmol} \mathrm{W} \mathrm{g}^{-1}$; this is slightly higher than the levels reached at $\mathrm{pH} 6$. Again, for tungstate, the decrease of the fraction of polynuclear species (i.e., the predominance of the simple oxo complex $\mathrm{WO}_{4}{ }^{2-}$ ) corresponds to a progressive diminution of tungsten loading (Fig. SM1b of the supplementary material). In 2003, Gustafsson reported that the sorption of tungstate onto ferrihydrite was stronger than the accumulation of molybdate, despite very similar chemical characteristics and comparable $\mathrm{pK}_{\mathrm{a}}$ values [22]. This behavior was also reported by Xu et al. in 2006 [23] for the comparative sorption of Mo and W onto goethite.

The literature provides limited information regarding the tungstate-chitosan interaction, but tungsten sorption depends to a large extent on its aqueous chemistry. The most stable oxidation state of tungsten is $6+$, which forms some oxo complexes (e.g., mono-tungstate $\mathrm{WO}_{4}{ }^{2-}$, para-tungstate $\mathrm{A}$ $\mathrm{W}_{7} \mathrm{O}_{24}{ }^{6-}$ and para-tungstate $\mathrm{B}_{2} \mathrm{~W}_{12} \mathrm{O}_{42}{ }^{10-}$ ). Generally, non-protonated monomeric species $\left(\mathrm{WO}_{4}{ }^{2-}\right)$ are the most stable under neutral to alkaline conditions because acidic $\mathrm{pH}$ promotes polymerization leading to the formation of polytungstate species $[24,25]$. At $\mathrm{pH} 8$, the predominant species is the polytungstate $\mathrm{W}_{6} \mathrm{O}_{21}{ }^{6-}$. Gecol et al. in 2006 [26] suggested that an electrostatic mechanism is responsible for tungstate binding on chitosan: in acidic solutions, the protonation of amine groups enhances the attraction of polynuclear anionic species (anionic polytungstate species). In this case, when working at $\mathrm{pH} 6$, the amount of $\mathrm{W}$ loaded (3.02 $\mathrm{mmol} \mathrm{W} \mathrm{g}^{-1}$ ) has little variation compared to the amount loaded at $\mathrm{pH} 8$. However, as the $\mathrm{pH}$ of the coagulation bath decreases, it becomes more difficult to form the beads due to the dissolution of chitosan in the acidic medium.

\section{Chemical Stability of Beads}

Preliminary studies and previous work have pointed out the presence of traces of free, absorbed, or weakly bound molybdate in the polymer network. This little fraction is relatively mobile, and its release into the solution may cause the complexation of $\mathrm{As}(\mathrm{V})$, which, in turn, may be less available for binding on the composite sorbent. Preliminary tests on these sorbents have shown that a fraction of arsenic remained unavailable to the sorbents, consistently with the previous comment. A dilute solution of phosphoric acid for removing this labile fraction of molybdate (and tungstate) from polymer network is used because of the affinity of phosphoric acid for desorbing molybdate (and tungstate) [13]. Figure 2 shows the amount of molybdate and tungstate loaded into the beads before and after washing with a solution of phosphoric acid 

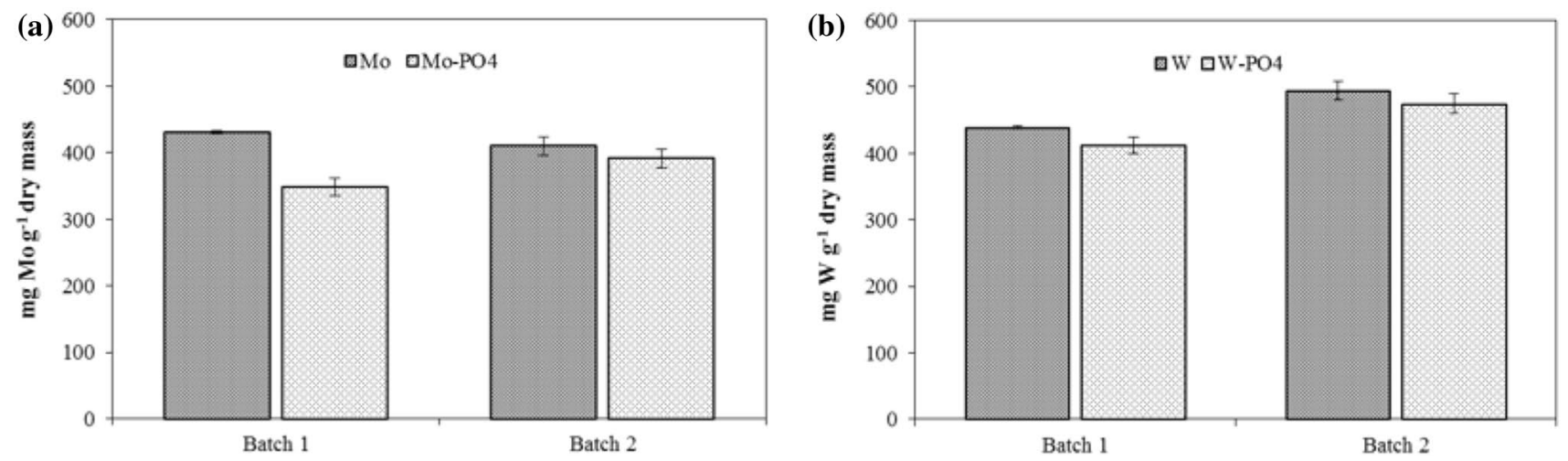

Fig. 2 Variation of the total amount of a molybdate $\left(\mathrm{pH} 7, \mathrm{C}_{0}: 7 \mathrm{~g} \mathrm{Mo} \mathrm{L}^{-1}\right)$ and $\mathbf{b}$ tungstate $\left(\mathrm{pH} 8, \mathrm{C}_{0}: 7 \mathrm{~g} \mathrm{~W} \mathrm{~L}^{-1}\right)$ content in two different batches of chitosan beads, before and after treatment with phosphoric acid $0.1 \mathrm{M}$

$0.1 \mathrm{M}$, for two different batches. As expected, in both cases, the metal loading in the beads decreases after the treatment with phosphoric acid: for molybdate-loaded sorbent, the average value decreases $12 \%$, while for tungstate-loaded the metal loading decreases only $5 \%$. Phosphate, molybdate, and tungstates are tetrahedral oxyanions that strongly bind adsorbates that share similar characteristics in terms of ionproton sorption; thus, they compete for the adsorption sites [27]. However, the most significant decrease in molybdenum content could be attributed to the formation of phosphomolybdate species; indeed, phosphate can react with molybdate when present at high concentration [23].

\section{SEM-EDX Characterization of Beads}

The type of drying may drastically change the structure of the beads. Figure 3 compares the environmental scanning electron micrographs of the CTS-Mo and CTS-W beads after ovendrying and freeze-drying processes. Molybdate and tungstate beads that were freeze-dried exhibit a highly porous structure, formed by the voids left by the removed solvent, due to the fact that the sample should be kept below the glass transition temperature when removing the frozen solvent under vacuum; the solvent then acts as a porogen to produce this type of structure in materials, which is well documented [28]. On the other hand, the oven-drying technique leads to the formation of highly compact structures due to the elimination of water molecules during the process increases the concentration of the solvent, creating a fluid drag, the particles then tend to form aggregates of higher stability [29]. The oven-drying does not allow managing capillary forces during the drying process as it may occur with freeze-drying and even better with drying under supercritical $\mathrm{CO}_{2}$ conditions [30,31]. The drying process affects the diameter of the beads: for CTS-Mo beads, it changes from $1.02 \pm 0.11 \mathrm{~mm}$ when freeze-dried to $0.44 \pm 0.06 \mathrm{~mm}$ when oven-dried. Similar changes are for
CTS-W beads: their diameter decreases from $1.06 \pm 0.12 \mathrm{~mm}$ to $0.46 \pm 0.07 \mathrm{~mm}$, respectively. The distribution of molybdenum and arsenic is roughly homogeneous (Fig. SM2 of the supplementary material); this means that chitosan ionotropic gelation with molybdenum is occurring in the whole mass of the beads and that arsenic is spread in the entire volume (i.e., all molybdate reactive groups are accessible; no concentration gradient was detected). The freeze-drying process allows the formation of a wide-open structure compared to a dense material formed in the oven-drying process; this is expected to influence mass transfer properties, diffusion, and uptake kinetics.

\section{Specific Surface Area}

The results of SSA are shown in Table 1, as expected, they are consistent with SEM analysis. The morphology of the oven-dried beads leads to the loss of pores in the material, thus obtaining a very low surface area; this is consistent with the time required for this material to reach the sorption equilibrium. The surface area of the CTS-W oven-dried beads is the lowest with a value of less than $1.0 \mathrm{~m}^{2}$. When the surface area is relatively small, (NIST considers $<2 \mathrm{~m}^{2} \mathrm{~g}^{-1}$ ) [32] it is recommended to use krypton instead of nitrogen; however, the equipment manufacturer reports that it is possible to measure absolute surface areas as low as $0.5-1.0 \mathrm{~m}^{2}$ using nitrogen as adsorption gas [33]. On the other hand, freeze-dried beads retain the porous structure with a surface area 20 times greater than that of oven-dried beads, which implies an adsorption process much faster at the beginning.

\section{FTIR Characterization for Beads Interactions}

Interaction Between Chitosan and Mo or W Groups Metal speciation controls molybdate/chitosan interactions and affects the predominance of polynuclear anionic species 
Fig. 3 SEM micrographs and EDX element cartographies of CTS-Mo and CTS-W beads, oven-dried and freeze-dried

\begin{tabular}{|c|c|c|}
\hline Sorbent & Raw & Mo or W loaded \\
\hline Oven-dried Mo & & \\
\hline Freeze-dried Mo & & \\
\hline Oven-dried W & & \\
\hline Freeze-dried W & & \\
\hline
\end{tabular}

Table 1 Specific surface area for CTS-Mo and CTS-W beads, freeze and oven-dried

\begin{tabular}{lll}
\hline Sorbent & \multicolumn{2}{l}{ Specific surface area, $\mathrm{m}^{2} \mathrm{~g}^{-1}$} \\
\cline { 2 - 3 } & Oven-dried & Freeze-dried \\
\hline CTS-Mo & 1 & 24 \\
CTS-W & $<1$ & 22 \\
\hline
\end{tabular}

[21]. Heptamolybdate species have a high anionic charge, which allows polyoxyanions to react with the protonated amino groups of the same or different chitosan chains. Also, the presence of a large number of oxygen atoms and -OH groups allow the formation of additional hydrogen bonds. Thus, multiple reactions lead to strengthening the structure of the beads [13]. Tungstate ions may behave similar to molybdate ions, due to the type of polynuclear anionic species present in the coagulation bath. Figure 4 shows the FTIR spectra of three samples: CTS beads coagulated by the traditional method (NaOH bath), and CTS-Mo and CTS-W beads formed by the ionotropic gelation method in Mo and W baths, respectively. The CTS beads spectrum (black) exhibits the characteristic bands of the CTS biopolymer. In the region of 3600 to $3000 \mathrm{~cm}^{-1}$, the stretch bands of

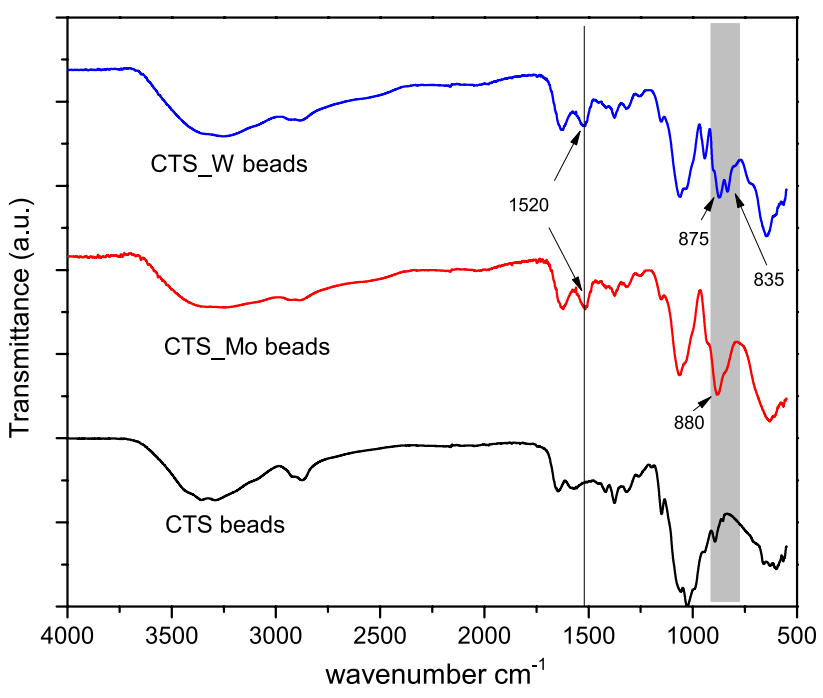

Fig. 4 FTIR spectra of CTS, CTS-Mo, and CTS-W beads

the amino- $\mathrm{NH}_{2}$ and hydroxyl-OH groups appear as a broad peak due to the multiple hydrogen bonding. The bands at $2875-2930 \mathrm{~cm}^{-1}$ are due to stretching of $-\mathrm{CH}$ groups. The amide I and amide III bands confirm the presence of residual $\mathrm{N}$-acetyl groups at $1645 \mathrm{~cm}^{-1}$ for $\mathrm{C}=\mathrm{O}$ stretching vibration 
(amide I band) and at $1315 \mathrm{~cm}^{-1}$ for the stretching of $\mathrm{C}-\mathrm{N}$ group (amide III). The band at $1538 \mathrm{~cm}^{-1}$ is due to the $\mathrm{NH}$ bending. At $1403 \mathrm{~cm}^{-1}$ appears the vibration of $\mathrm{OH}$ group in the ring and at $1370 \mathrm{~cm}^{-1}$, the vibration of $\mathrm{CH}_{3}$ of the amide group. The bands around 1057 and $1030 \mathrm{~cm}^{-1}$ correspond to the $\mathrm{C}-\mathrm{O}-\mathrm{C}$ stretching of the glycosidic linkage. Finally, the low-intensity bands at 850 and $838 \mathrm{~cm}^{-1}$ are due to the vibration of the $\mathrm{CH}_{3} \mathrm{COH}$ group $[34,35]$.

Concerning the oxyanions of Mo and $\mathrm{W}$, the region of the appearance of Mo-O and $\mathrm{W}-\mathrm{O}$ vibration bands, is practically the same for both metals [36]. The adsorption bands for Mo are reported in the region from $1000-700 \mathrm{~cm}^{-1}$ [37] and the stretching $\mathrm{W}-\mathrm{O}$ between $880-820 \mathrm{~cm}^{-1}$ [38]. The CTS-Mo beads spectrum (red) shows a peak at $880 \mathrm{~cm}^{-1}$ of medium intensity and a shoulder near $840 \mathrm{~cm}^{-1}$. The band at $850 \mathrm{~cm}^{-1}$ shifts to $880 \mathrm{~cm}^{-1}$ and increases its intensity, due to an interaction between $\mathrm{Mo}-\mathrm{O}$ and oxygen of $\mathrm{OH}$ groups of CTS; because the $880 \mathrm{~cm}^{-1}$ band also corresponds to the Mo-O-Mo bonds of the polynuclear species. These results are consistent with the mechanism proposed by Bertoni et al. in 2018 [39], where the hydroxyl groups of chitosan are the active binding sites to coordinate molybdate anions. According to their results, the protonated amino groups stabilize the negative charges of heptamolybdate anions, which in addition to the binding with hydroxyl groups, results in the retention of molybdate.

The CTS-W beads spectrum (blue) shows two defined peaks at 875 and $835 \mathrm{~cm}^{-1}$, which indicates an interaction between $\mathrm{W}-\mathrm{O}$ and $\mathrm{OH}$ groups of CTS. Besides, the band at $1538 \mathrm{~cm}^{-1}$ of NH bending of CTS shifts to $1520 \mathrm{~cm}^{-1}$ for both CTS-Mo and CTS-W beads; this is a characteristic band of the interaction of an amide II in CTS with metallic ions [37].

Interaction Between Mo or $W$ and As $(V)$ Dambies et al. [13] suggested the mechanism of adsorption of $\mathrm{As}(\mathrm{V})$ onto chitosan beads impregnated with molybdate. The arsenate complex with molybdate ions due to the formation of the molybdoarsenate complex. Later, in 2002, they confirmed by an XPS analysis that arsenic sorption could only occur in molybdate since the adsorption capacity of $\mathrm{As}(\mathrm{V})$ decreases if molybdate is chemically reduced [14].

Our FT-IR analysis (Fig. 5) performed on chitosan beads loaded with Mo and W before and after arsenic sorption confirms the formation of the molybdoarsenate complex with the disappearance of the $880 \mathrm{~cm}^{-1}$ band corresponding to the Mo-O asymmetric vibration and the appearance of a new characteristic peak of arsenate adsorption at $836 \mathrm{~cm}^{-1}$ due to the stretching vibration of As-O [40]. On the other hand, typical bands for the oxo complexes of $\mathrm{W}$ and As appear between 836 and $856 \mathrm{~cm}^{-1}$ due to the deformation of the $\mathrm{AsO}_{4}$ tetrahedron and bands between 682 and $783 \mathrm{~cm}^{-1}$ assigned to $\mathrm{W}-\mathrm{O}-\mathrm{W}$ and $\mathrm{WO}-\mathrm{As}$ bonds [41]

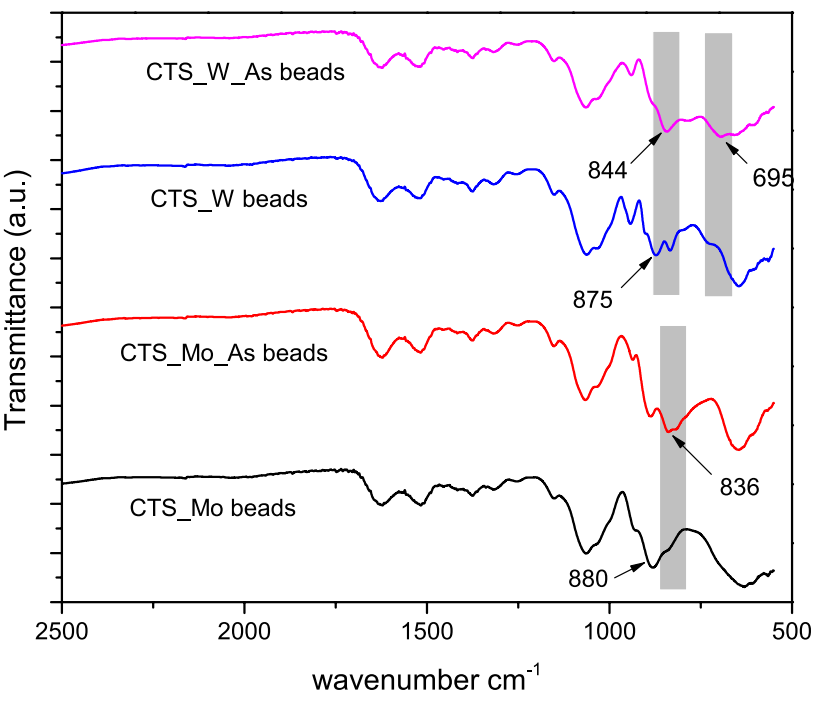

Fig. 5 FTIR spectra of CTS-Mo, and CTS-W beads, before and after $\mathrm{As}(\mathrm{V})$ sorption

Taking into account the results obtained from FTIR analysis in this work and the studies previously mentioned, we consider that the mechanism showed in Fig. 6 could describe the interaction between chitosan, molybdate, and arsenate, and we could expect, as has been discussed, a similar behavior with tungstate ions.

\section{Influence of pH in As (V) Sorption}

Figure 7 shows the influence of $\mathrm{pH}$ on As (V) sorption using oven-dried CTS-Mo and CTS-W beads. Plots represent arsenic sorption as a function of Mo and $\mathrm{W}$ mass accumulated in the beads, as well as the percentage released in the solution. The redox potential and $\mathrm{pH}$ are the most important factors that control arsenic speciation, under oxidizing conditions, and at $\mathrm{pH}$ below $6.9, \mathrm{H}_{2} \mathrm{AsO}_{4}{ }^{-}$is the dominant species [42]. This species predominates at $\mathrm{pH} 2.5$ and 4 with $75 \%$ and 99\%, respectively (Fig. SM3). Although the chemistry of molybdo-arsenic anions is complicated, a mechanism similar to complexation with arsenate ions has been established [13]. In the case of tungsten, very little information is available on the interaction of its anions with arsenic, although it is known that compounds such as WAs ${ }_{2}$ and WAs $\mathrm{W}_{3}$ exist in the tungsten-arsenic system [43]. For both sorbents, the optimum $\mathrm{pH}$ range turns out to be very similar: the best sorption occurs at $\mathrm{pH}$ close to 3 . It is noteworthy that this $\mathrm{pH}$ also corresponds to the lowest release of active metal ions (i.e., molybdate or tungstate). The low release of coordinating metal limits the competitive complexation of arsenic with metal ions for binding on reactive groups on the sorbents, so the sorption is enhanced. 
(a)

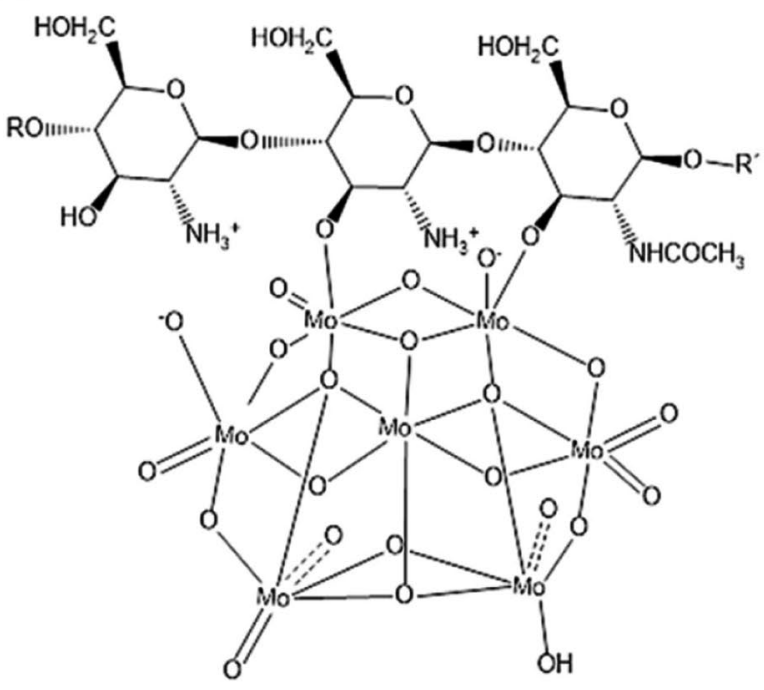

(b)

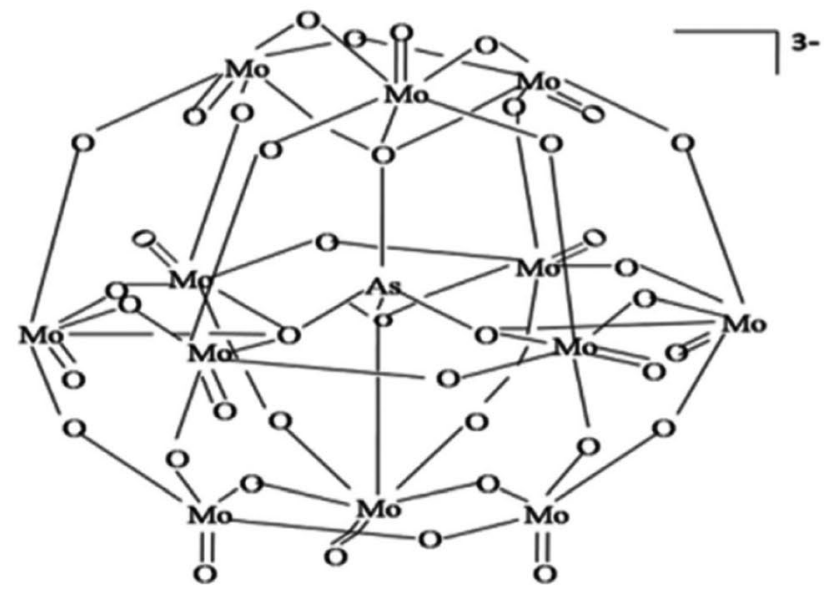

Fig. 6 a Possible mechanism for molybdate binding to chitosan (adapted from [39] with permission from ELSEVIER), b Possible structure of the arsenomolybdate complex (reproduced from [40] with permission from The Royal Society of Chemistry)

(a)

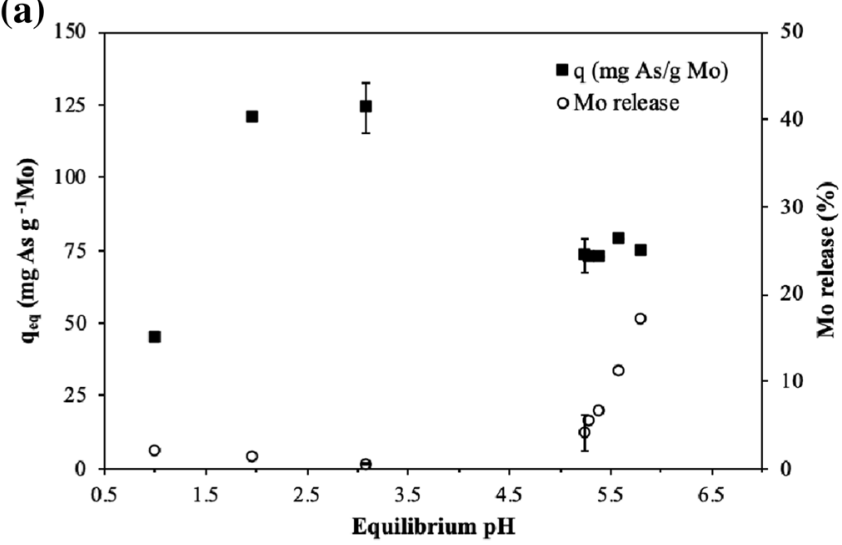

(b)

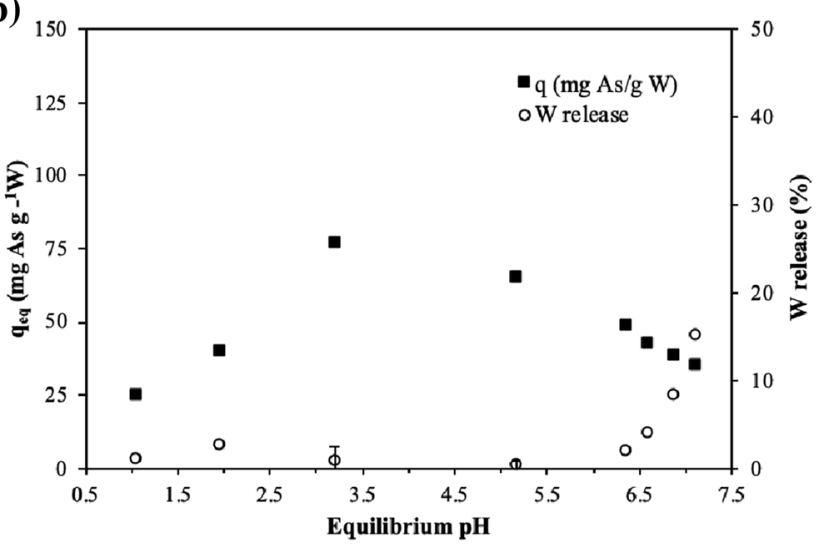

Fig. 7 Influence of $\mathrm{pH}$ on arsenic sorption for a CTS-Mo and b CTS-W beads. Sorbent dosage: $1.25 \mathrm{mg} \mathrm{mL}^{-1}, \mathrm{C}_{0}: 100 \mathrm{mg} \mathrm{As} \mathrm{L}^{-1}$, contact time: $72 \mathrm{~h}, \mathrm{~T}: 20^{\circ} \mathrm{C}$ (closed symbols: As sorption, open symbols: Mo and $\mathrm{W}$ release)

On the other hand, minimizing the release of molybdate and tungstate reduces the post contamination of the solution: substituting arsenic contamination by Mo or $\mathrm{W}$ contamination would not make sense. Above this $\mathrm{pH}$, the arsenic sorption begins to decrease, and the release of molybdenum and tungsten in the beads increases. At acidic $\mathrm{pH}$ (around $\mathrm{pH} 1$ ), the intense competition of protons and the speciation of arsenic are less favorable for metal binding; the sorption capacity sharply decreases.

\section{As (V) Sorption Isotherms}

Figure 8 shows a comparison between sorption isotherms of As (V) in CTS-Mo and CTS-W beads at pH 3, before and after treatment with phosphoric acid. As can be observed for both materials, sorption capacity is reduced after acid treatment, going from 1 to $0.82 \mathrm{mmol} \mathrm{As} \mathrm{g}^{-1}$ of dry mass (i.e., 116 to $108 \mathrm{mmol} \mathrm{As} \mathrm{g}^{-1} \mathrm{Mo}$ ) for CTS-Mo 

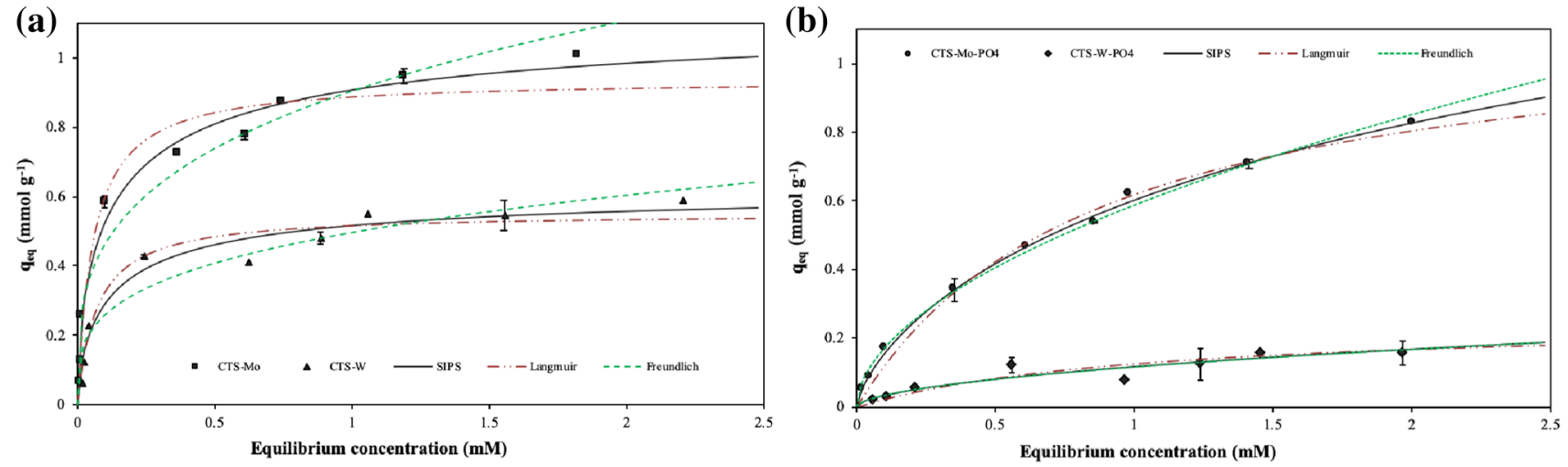

Fig. 8 Influence of the phosphoric acid treatment in CTS-Mo and CTS-W beads. a beads without treatment $\mathbf{b}$ beads treated with phosphoric acid. Sorbent dosage: $1 \mathrm{mg} \mathrm{mL}^{-1}, \mathrm{pH}: 3$, contact time: $140 \mathrm{~h}, \mathrm{~T}: 20^{\circ} \mathrm{C}$

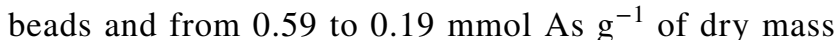
(i.e., 60.8 to $21.6 \mathrm{mmol} \mathrm{As}^{-1} \mathrm{~W}$ ) for CTS-W beads. This loss of capacity can be attributed to the fact that during treatment with phosphoric acid, not only the labile part of the metal is removed, but also phosphate anions could be bound to the sorbent surface. In this case, phosphate anions would compete directly with arsenate anions for available sites, due to the similarities existing between them. This behavior has been reported when studying the co-adsorption of some oxyanions on the goethite surface, positively charged. Paths followed by trivalent oxyanions group (vanadate, phosphate, and arsenate) during adsorption, are practically indistinguishable from each other [27]. In any case, the highest sorption capacity is reached with molybdate-loaded beads without treatment: $1 \mathrm{mmol}$ As $\mathrm{g}^{-1}$ dry mass, which represents an advantage in terms of simplicity and cost of the process.

The conventional models of Langmuir (Eq. 1) and Freundlich (Eq. 2) were used to adjust the experimental data using non-linear regression analysis. Besides, the SIPS model (which combines the Langmuir and the Freundlich equations, according to Eq. 3) was also tested for modeling the sorption isotherms. The best correlation coefficient is systematically obtained with the SIPS equation, although the values of Langmuir are very close. It is noteworthy that the adjustment of the isotherm profile for tungstate-loaded beads treated with phosphoric acid is very poor, regardless of the fitting model used; this is probably due to the very low sorption capacities obtained with this treated sorbent (i.e., less than $0.19 \mathrm{mmol} \mathrm{As}^{-1}$ ).

$q_{e q}=q_{m} K_{L} \frac{c_{e q}}{1+K_{L} C_{e q}}$

$q_{e q}=K_{f} C_{e q}^{1 / n}$

$q_{e q}=\frac{q_{m}\left(b c_{e q}\right)^{1 / n}}{1+b c_{e q}^{1 / n}}$

Table 2 shows the parameters determined for each model used. Langmuir equation indicates monolayer sorption on
Table 2 Sorption isothermsmodeling parameters for Langmuir, Freundlich, and SIPS equations

\begin{tabular}{|c|c|c|c|c|c|}
\hline Model & Parameter & Mo & $\mathrm{Mo}-\mathrm{PO}_{4}$ & $\mathrm{~W}$ & $\mathrm{~W}-\mathrm{PO}_{4}$ \\
\hline \multirow{5}{*}{ Langmuir } & 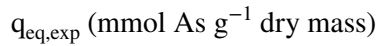 & 1.007 & 0.826 & 0.590 & 0.0192 \\
\hline & 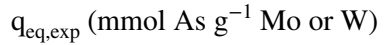 & 116.076 & 108.122 & 60.762 & 21.640 \\
\hline & $\mathrm{q}_{\mathrm{eq}, \mathrm{cal}}\left(\mathrm{mmol} \mathrm{As} \mathrm{\textrm {g } ^ { - 1 } )}\right.$ & 0.927 & 1.109 & 0.545 & 0.194 \\
\hline & $\mathrm{K}_{\mathrm{L}}\left(\mathrm{L} \mathrm{mmol}^{-1}\right)$ & 20.743 & 1.291 & 15.057 & 1.901 \\
\hline & $\mathrm{R}^{2}$ & 0.964 & 0.989 & 0.950 & 0.800 \\
\hline \multirow[t]{3}{*}{ Freundlich } & $\mathrm{K}_{\mathrm{F}}\left(\mathrm{mmol} \mathrm{g}^{-1}\right) /\left(\mathrm{mmol} \mathrm{L}^{-1}\right)^{\mathrm{n}}$ & 0.902 & 0.593 & 0.492 & 0.119 \\
\hline & $\mathrm{n}$ & 3.507 & 1.914 & 3.630 & 2.405 \\
\hline & $\mathrm{R}^{2}$ & 0.939 & 0.992 & 0.910 & 0.803 \\
\hline \multirow[t]{4}{*}{ SIPS } & $\mathrm{q}_{\mathrm{eq}, \mathrm{cal}}\left(\mathrm{mmol} \mathrm{As} \mathrm{g}^{-1}\right)$ & 1.087 & 1.908 & 0.587 & 0.406 \\
\hline & $1 / \mathrm{n}$ & 0.681 & 0.703 & 0.804 & 0.608 \\
\hline & $\mathrm{B}\left(\mathrm{mL} \mathrm{mmol} \mathrm{As}{ }^{-1}\right)$ & 4.914 & 0.469 & 6.867 & 0.414 \\
\hline & $\mathrm{R}^{2}$ & 0.974 & 0.997 & 0.952 & 0.811 \\
\hline
\end{tabular}


the homogeneous surface sites of beads [44]. The equilibrium amount of metal sorbed per unit weight of sorbent is $\mathrm{q}_{\mathrm{e}}$; the equilibrium concentration of metal in aqueous solution is $\mathrm{C}_{\mathrm{e}}$; the maximum sorption capacity of the sorbent at saturation of the monolayer is $\mathrm{q}_{\mathrm{m}}$, and $\mathrm{K}_{\mathrm{L}}$ is the Langmuir equilibrium coefficient. For composite materials and some chitosan beads, the Freundlich isotherm can also describe the sorption process, where $\mathrm{K}_{\mathrm{F}}$ and $\mathrm{n}$ are the Freundlich constants, which are indicators of the capacity and intensity of sorption, respectively. However, it can be assumed that chitosan-derived materials present heterogeneities of the sorption sites, and the sorption process could be different form monolayer [45]. The SIPS isotherm model—which gives the best fitting for the equilibrium data- includes three different parameters: $q_{m}$ is the total number of binding sites, $b$ is the constant average association, and $1 / n$ is the factor of heterogeneity. When the factor of heterogeneity is less than one, the sorbent is heterogeneous; but when it is close to the unit, it represents more homogeneous binding sites. This model is more suitable for predicting sorption on heterogeneous surfaces, but if the adsorbate concentration is very low, the model reduces to Freundlich's, and if the adsorbate concentration is high, the model reduces to Langmuir's [46, 47].

Table 3 shows sorption properties on different chitosanbased sorbents. Given the different nature and experimental conditions for each process, it is difficult to make a direct comparison among the sorbents. However, it gives an overview of the potential of molybdate- and tungstate-loaded beads in the removal of $\mathrm{As}(\mathrm{V})$. The sorption capacity of CTS-Mo beads is well above several of the compared sorbents; however, there are some reported sorbents with higher sorption capacity than our material $[8,48-50]$. Although this should not be the only parameter to consider: the complexity of materials and manufacturing processes, as well as the necessary sorbent dosage, should also be considered because we are looking for a relatively simple manufacturing process. For example, it is not inexpensive nor straightforward to prepare nanofibers of cellulose acetate/chitosan/SWCNT/ $\mathrm{Fe}_{3} \mathrm{O}_{4} / \mathrm{TiO}_{2}[48]$ or chitosan magnetic material after pyrolysis at $550{ }^{\circ} \mathrm{C}$ [49] (pyrolysis will degrade chitosan into char with no $\mathrm{NH}$ nor $\mathrm{OH}$ functional groups at all). And even the sorption capacity of CTS-W beads is lower than that of CTS-Mo, it is still competitive compared to other chitosanbased sorbents.

\section{Influence of Drying on Sorption Kinetics}

Figure 9 compares sorption kinetics for CTS-Mo and CTS-W beads subjected to three different treatments: ovendried, freeze-dried, and wet (not dried). For both sorbents, the kinetic curve representing the oven-dried process presents a long initial stage where the sorbent is practically unable to uptake metal ions of the solution, which can be explained by the restriction in the porosity of this material. The oven-drying process leads to an irreversible reduction in the size and shape of beads, which in turn causes a decrease in the size and volume of pores that hinder the diffusion process [51]. Even the sorption capacity is not much lower than that of freeze-dried beads, the equilibrium time is considerably longer, needing more than $48 \mathrm{~h}$ to reach equilibrium. The kinetic curve for freeze-dried beads present a much faster ion uptake at the beginning, and the equilibrium is reached

Table $3 \mathrm{As}(\mathrm{V})$ sorption capacity comparison for several chitosan-based sorbents

\begin{tabular}{|c|c|c|c|c|}
\hline Sorbent & $\mathrm{pH}$ range & $\begin{array}{l}\text { Sorption } \\
\text { capacity (mg } \\
\left.\mathrm{g}^{-1}\right)\end{array}$ & $\begin{array}{l}\text { Sorbent } \\
\text { dosage (mg } \\
\left.\mathrm{mL}^{-1}\right)\end{array}$ & Reference \\
\hline Cellulose acetate/chitosan/SWCNT/ $\mathrm{Fe}_{3} \mathrm{O}_{4} / \mathrm{TiO}_{2}$ composite nanofibers & 3.0 & 281.5 & 0.5 & [48] \\
\hline Chitosan stabilized magnetic material after pyrolysis at $550{ }^{\circ} \mathrm{C}$ & 6.0 & 101 & 4 & [49] \\
\hline Molybdate-loaded chitosan beads & 3.0 & 75 & 1 & This work \\
\hline Chitosan-functionalized graphene oxide & $4.3-6.5$ & 71.9 & 8 & [8] \\
\hline Cross-linked magnetic chitosan anthranilic acid glutaraldehyde Schiff's base & 2.0 & 62.42 & 0.5 & {$[50]$} \\
\hline Tungstate-loaded chitosan beads & 3.0 & 44 & 1 & This work \\
\hline Fe-Mn binary oxide impregnated chitosan bead & 7.0 & 39.1 & 1 & {$[54]$} \\
\hline Chitosan $/ \mathrm{Cu}(\mathrm{OH})_{2}$ composite & 4.0 & 39.1 & 2.5 & {$[55]$} \\
\hline Chitosan/CuO composite & 4.0 & 28.1 & 2.5 & {$[55]$} \\
\hline Chitosan beads immobilized with iron(III) & 7.0 & 27.59 & 5 & {$[56]$} \\
\hline Iron coated chitosan & 7.0 & $22.47 \pm 0.56$ & 5 & {$[57]$} \\
\hline Granular adsorbent made of iron-containing backwashing residual sludge and chitosan & 6.5 & 14.995 & 1 & {$[58]$} \\
\hline Zerovalent iron impregnated chitosan-caboxymethyl- $\beta$-cyclodextrin composite beads & 6.0 & 13.51 & 3.33 & [59] \\
\hline Chitosan goethite bionanocomposite & $5.0-9.0$ & 11.3 & 2.5 & [60] \\
\hline
\end{tabular}


(a)

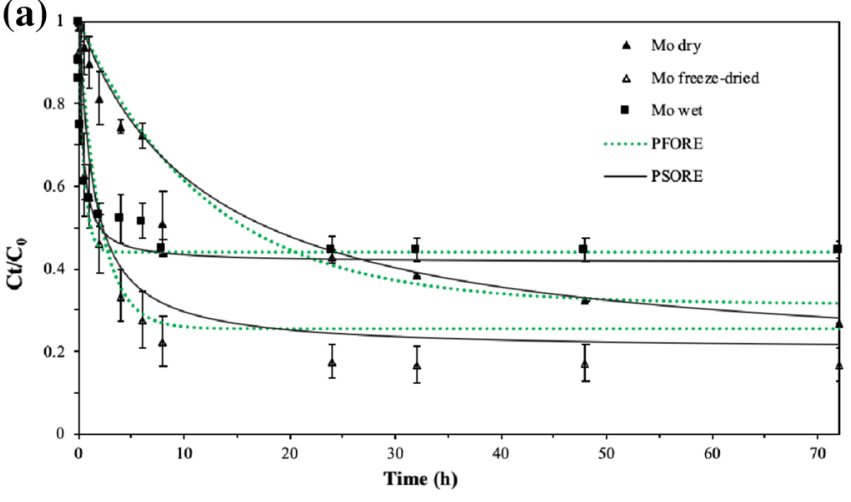

(b)

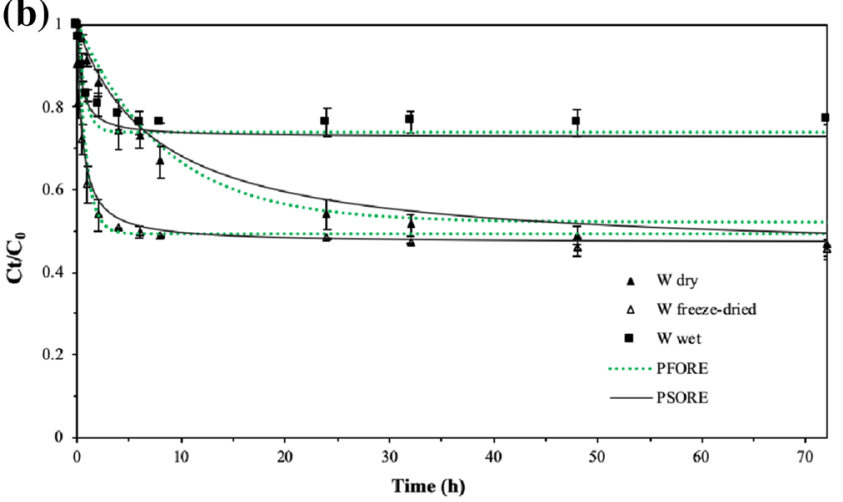

Fig. 9 Influence of drying process on As(V) sorption. PFORE and PSORE kinetic models for a CTS-Mo, and b CTS-W beads. Sorbent dosage:

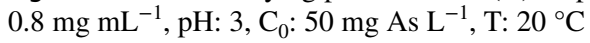

in less than $24 \mathrm{~h}$, favored, in this case, by the high porosity of the sorbent. Despite the favorable effect of freeze-drying on the mass transfer properties, this is an expensive drying process, and the cost-benefit balance should be evaluated for justifying the use of this method. As expected, wet beads show the faster kinetic profiles; this is consistent with conclusions reported on the sorption of dyes on chitosan beads [52]. The first part of the curve has an ion taking almost as fast as freeze-dried beads, and, in the same way, the equilibrium time is less than $24 \mathrm{~h}$; however, its sorption capacity is considerably lower. The above can be attributed mainly to the loss of stability over time since most of the beads get cracked during the process, which also limits their lifetime and prevents reuse.

Pseudo-first (PFORE) and pseudo-second (PSORE) order rate equations (see supplementary material section) were used to adjust the experimental data. These models describe kinetics reactions for homogeneous systems, but they are also commonly used to model sorption kinetics for heterogeneous systems. In general, the pseudo-second-order model predicts the experimental profiles more efficiently. Table 4 shows the parameters determined for each model.

Although PSORE describes adequately kinetic experimental data, the model does not provide information regarding the adsorption mechanism. In such cases, the intraparticle diffusion model can be useful to identify the mechanism and predict the rate-controlling step. Experimental data is linearized to the intraparticle diffusion model. CTS-Mo and CTS-W beads exhibit two linear regions (Fig. SM4 of the supplementary material), indicating that the sorption process is controlled by a multistep mechanism instead of being entirely governed by intraparticle diffusion [53]. Table SM1 (of the supplementary material) shows the parameters calculated for the intraparticle diffusion model.

\section{Effect of Competitor lons}

The influence of other anions $\left(\mathrm{PO}_{4}{ }^{3-}, \mathrm{SO}_{4}{ }^{2-}, \mathrm{NO}_{3}{ }^{-}, \mathrm{Cl}^{-}\right)$is considered to evaluate the efficiency of the proposed sorbent in the presence of different species from industrial effluents or natural waters In a second step, the competition of base metals has been investigated using a simulated effluent that contained: $\mathrm{Cu}$ (II), $\mathrm{Zn}(\mathrm{II}), \mathrm{Ni}(\mathrm{II})$, and $\mathrm{Cd}(\mathrm{II})$. Figure 10 shows the variation in sorption capacity in three different concentrations of co-existing ions. Chloride ions have the least influence on sorption capacity: a considerable excess (i.e., 100:1 ratio) was required for detecting a slight decrease in $\mathrm{As}(\mathrm{V})$ binding. Nitrate ions have a limited impact on sorption performance, especially for CTS-W beads: large

Table 4 Sorption kinetics - modeling parameters for PFORE and PSORE kinetic models

\begin{tabular}{|c|c|c|c|c|c|c|c|}
\hline \multirow[t]{2}{*}{ Model } & \multirow[t]{2}{*}{ Parameter } & \multicolumn{3}{|l|}{ Mo } & \multicolumn{3}{|l|}{ W } \\
\hline & & Oven-dried & Freeze-dried & Wet & Oven-dried & Freeze-dried & Wet \\
\hline \multirow[t]{3}{*}{ PFORE } & $\mathrm{q}_{\mathrm{eq}}\left(\mathrm{mmol} \mathrm{As} \mathrm{g}-{ }^{1}\right)$ & 0.590 & 0.654 & 0.503 & 0.426 & 0.428 & 0.222 \\
\hline & $k_{l}\left(\min ^{-1}\right)$ & $1.38 \times 10-3$ & $8.33 \times 10^{-3}$ & $32.1 \times 10^{-3}$ & $2.00 \times 10-3$ & $20.4 \mathrm{x} \times 10^{-3}$ & $24.4 \times 10^{-3}$ \\
\hline & $\mathrm{R}^{2}$ & 0.981 & 0.976 & 0.968 & 0.993 & 0.972 & 0.969 \\
\hline \multirow[t]{3}{*}{ PSORE } & $\mathrm{q}_{\mathrm{eq}}\left(\mathrm{mmol} \mathrm{As} \mathrm{g} \mathrm{g}^{-1}\right)$ & 0.724 & 0.701 & 0.526 & 0.498 & 0.448 & 0.233 \\
\hline & $k_{2}\left(\mathrm{~g} \mathrm{mmol}^{-1 \mathrm{~min} 1}\right)$ & $1.87 \times 10-3$ & $17.9 \times 10^{-3}$ & $95.9 \times 10^{-3}$ & $4.41 \times 10-3$ & $73.5 \times 10^{-3}$ & $163 \times 10^{-3}$ \\
\hline & $\mathrm{R}^{2}$ & 0.985 & 0.995 & 0.993 & 0.997 & 0.989 & 0.973 \\
\hline
\end{tabular}



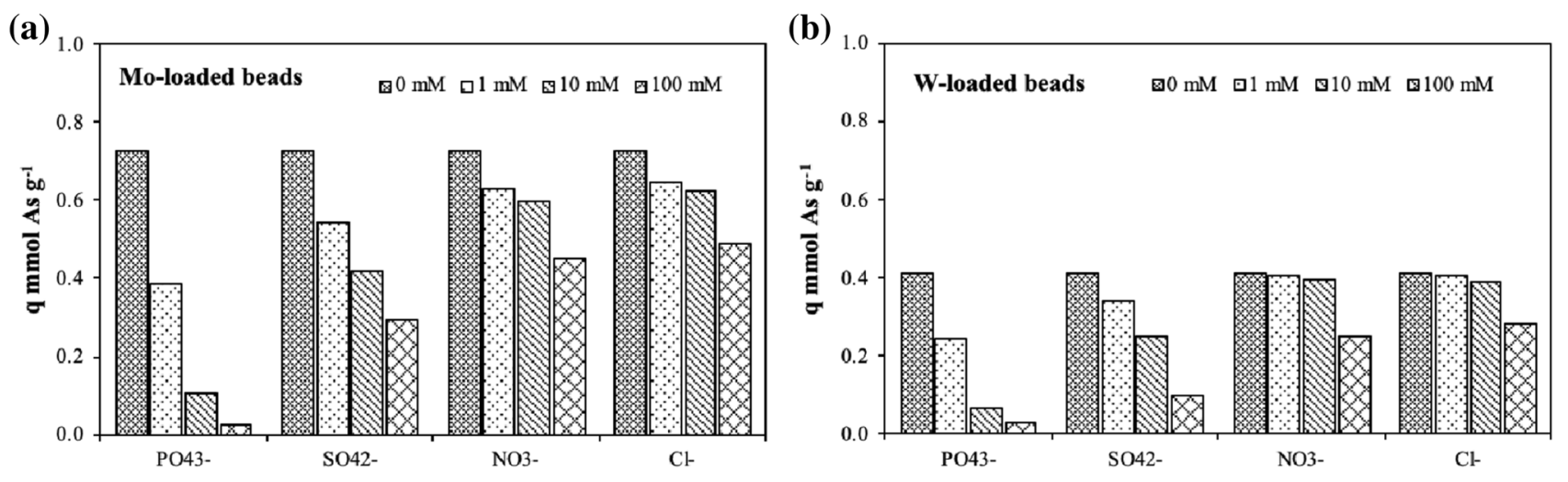

Fig. 10 Effect of co-existing anions on As(V) sorption for a CTS-Mo and b CTS-W beads. Sorbent dosage: $1 \mathrm{mg} \mathrm{mL}{ }^{-1}$, pH: 3 , contact time: $140 \mathrm{~h}, \mathrm{~T}: 20^{\circ} \mathrm{C}$

excess (i.e., 100:1 ratio) is necessary for a slight decrease in uptake performance. For CTS-Mo beads, the effect of nitrate ions can be detected when the competitor anion is in excess compared to arsenate anions Sulfates and phosphates are undoubtedly the ions that cause the greatest effect on sorption capacity, this being even greater with phosphate ions. As explained before, phosphate ions share similarities with arsenate ions, and thus compete for sorption sites and reduce its sorption capacity almost completely when the ratio phosphate:arsenate is $100: 1$. This different effect for other ions present in the solution supports the interpretation of the mechanism as complexation rather than an ion exchange.

The presence of other cations, such as those present in effluents of the mining industry, has a higher impact on arsenic sorption. The two effluents taken as a basis to simulate the actual concentrations of different metals have a high sulfate content respect to arsenic (i.e., 30:1 ratio). Table 5 shows the initial concentration of $\mathrm{Cu}, \mathrm{Zn}, \mathrm{Ni}, \mathrm{Cd}$, and As for both effluents; as can be observed, even when the sorption capacity for other metals is deficient, the arsenic sorption capacity is affected. For CTS-Mo, a maximum capacity of $0.69 \mathrm{mmol} \mathrm{As} \mathrm{g}^{-1}$ is reached, while CTS-W

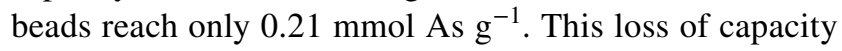
can also be attributed to the high sulfate content, which, as was explained, has the greatest impact on arsenic sorption due to direct competition for active sites.

\section{Arsenic Desorption and Sorbent Reuse}

Desorption on CTS-Mo beads had been successfully tested using phosphoric acid 0.1 M [14]; this eluent was also tested for As (V) removal from CTS-W beads. Figure 11 shows the sorption efficiency for beads after three cycles. The CTS-Mo beads show only a slight decrease in sorption capacity in the second cycle, but it is recovered again in the third. The sorption capacity for each cycle is $0.71 \pm 0.02,0.68 \pm 0.01$, and $0.75 \pm 0.04 \mathrm{mmol} \mathrm{As} \mathrm{g}^{-1}$, respectively. On the opposite side, there is a continuous decrease in the sorption capacity of CTS-W beads throughout the three cycles. The sorption capacity for each cycle is $0.54 \pm 0.07,0.33 \pm 0.01$, and $0.24 \pm 0.04 \mathrm{mmol} \mathrm{As} \mathrm{g}^{-1}$, respectively. This behavior can be attributed to a progressive saturation of the active sites,
Table 5 Effect of co-existing metal ions on $\mathrm{As}(\mathrm{V})$ sorption in a simulated effluent

\begin{tabular}{|c|c|c|c|c|}
\hline Effluent & Metal ion & $\mathrm{C}_{0}(\mathrm{mM})$ & 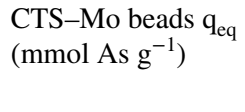 & $\begin{array}{l}\text { CTS-W beads } \\
\mathrm{q}_{\mathrm{eq}}(\mathrm{mmol} \mathrm{As} \\
\left.\mathrm{g}^{-1}\right)\end{array}$ \\
\hline \multirow{4}{*}{$\begin{array}{l}\text { Effluent } 1 \\
\text { (Dziubek [20]) }\end{array}$} & $\mathrm{Cu} 2+$ & 0.202 & 0.003 & 0.007 \\
\hline & $\mathrm{Zn} 2+$ & 0.042 & 0.001 & 0.004 \\
\hline & $\mathrm{Ni} 2+$ & 0.029 & 0 & 0 \\
\hline & As5+ & 3.785 & 0.694 & 0.210 \\
\hline \multirow{5}{*}{$\begin{array}{l}\text { Effluent } 2 \\
\text { (Basha et al. [19]) }\end{array}$} & $\mathrm{Cu} 2+$ & 0.237 & 0.008 & 0.011 \\
\hline & $\mathrm{Zn} 2+$ & 0.318 & 0.011 & 0.004 \\
\hline & $\mathrm{Ni} 2+$ & 0.022 & 0 & 0.005 \\
\hline & $\mathrm{Cd} 2+$ & 0.051 & 0.001 & 0.037 \\
\hline & As5+ & 4.021 & 0.669 & 0.211 \\
\hline
\end{tabular}




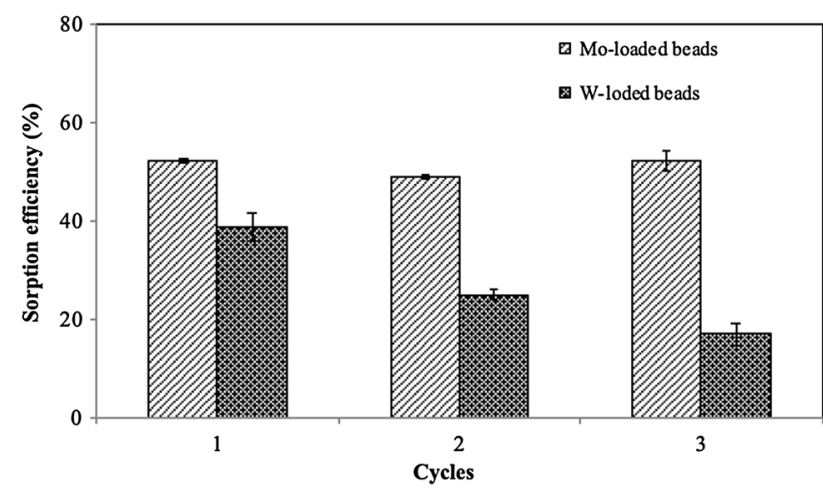

Fig. 11 Reuse of CTS-Mo and CTS-W chitosan beads. Desorption step-desorption agent: $\mathrm{H}_{3} \mathrm{PO}_{4} 0.1 \mathrm{M}$, sorbent dosage: $0.5 \mathrm{mg} \mathrm{mL}{ }^{-1}$, contact time: $24 \mathrm{~h}, \mathrm{~T}: 20^{\circ} \mathrm{C}$

considering the desorption efficiency decreases with each cycle. Furthermore, based on the previous treatment with phosphoric acid, there is no evidence that it removes the tungstate bound to chitosan. Tungstate beads were also tested for desorption with $0.1 \mathrm{M} \mathrm{NaOH}$ (not shown); after the first and second cycle, the desorption percentage reached is higher than its equivalent with phosphoric acid. However, beads do not remain stable in the solution, after cycles with a considerable sorbent mass loss, which may indicate reversibility in the ionotropic gelation process.

\section{Conclusions}

The molybdate and tungstate ions can form complexes with $\mathrm{As}(\mathrm{V})$ in solution, which improves the sorption properties of chitosan with arsenic. In this case, and contrary to the previous report for coagulated beads in molybdate solution, additional treatment with phosphoric acid does not improve the sorption capacity of molybdate or tungstate beads. Sorption capacities reached 75 and $44 \mathrm{mg} \mathrm{As} \mathrm{g}^{-1}$ of dry mass in CTS-Mo and CTS-W beads, respectively. The drying process reveals a higher sorption rate at the beginning of the process for freeze-dried beads; however, when reaching equilibrium, their capacity is not much higher than the capacity reached of oven-dried beads.

Regarding the competition with other ions, the most significant impact on arsenic sorption is caused by the presence of phosphate ions, even at a 1:1 ratio, due to similarities between phosphate and arsenate ions, and thus compete for sorption sites.

Desorption was carried out with phosphoric acid through 3 cycles, CTS-Mo beads presented a better sorption capacity and, therefore, longer reuse time; in contrast to CTS-W beads, which maintained a decrease in sorption capacity throughout the cycles.
CTS-W and CTS-Mo beads are interesting materials for efficient removal of $\mathrm{As}(\mathrm{V})$ from acid solutions in the treatment of residual water compared to other chitosan-based sorbents.

Acknowledgement National Council for Science and Technology-CONACYT. Scholarship \# 401226 and scholarship as visiting research student at Ecole des Mines d'Alès, France. We want to thank Prof. Fierro-González for helping with specific surface area analysis, Prof. Almendárez-Camarillo for helping with SEM images, and Prof. Galindo-Vallarino for assistance with FTIR analysis.

\section{References}

1. Mohan D, Pittman C Jr (2007) J Hazard Mater 142:1-53

2. Navarro O, González J, Júnez-Ferreira H, Bautista C-F, Cardona A (2017) Procedia Eng 186:333-340

3. Missimer TM, Teaf CM, Beeson WT, Maliva RG, Woolschlager J, Covert DJ (2018) Int J Environ Res Public Health 15:1-30

4. Rahman M, Rahman A, Kaiser Khan M, Renzaho AM (2018) Ecotoxicol Environ Saf 150:335-343

5. Bhowmick S, Pramanik S, Singh P, Mondal P, Chatterjee D, Nriagu J (2018) Sci Total Environ 612:148-169

6. Kwok K, Koong LF, Chen G, McKay G (2014) J Colloid Interface Sci 416:1-10

7. Guibal E (2004) Sep Purif Technol 38:43-74

8. Kumar AS, Jiang SJ (2016) J Environ Chem Eng 4:1698-1713

9. Ngah W, Endud C, Mayanar R (2002) React. Funct. Polym 50:181-190

10. Pang M, Kano N, Imaizumi H (2015) J Chem Chem Eng 9:433-441

11. Beheshti H, Irani M, Hosseini L, Rahimi A, Aliabadi M (2016) Chem Eng J 284:557-564

12. Wang Y, Li L, Luoa C, Wanga X, Duan H (2016) Int J Biol Macromol 86:505-511

13. Dambies L, Guibal E, Roze A (2000) Colloids Surf A 170:19-31

14. Dambies L, Vincent T, Guibal E (2002) Water Res 36:3699-3710

15. Gibert F, Moine B, Schott J, Dandurand JL (1992) Contrib Mineral Petrol 112:371-384

16. Rinaudo M (2006) Prog Polym Sci 31:603-632

17. Kasaai MR (2007) Carbohydr Polym 68:477-488

18. Brunauer S, Emmett P, Teller E (1938) J Am Chem Soc 60:309-319

19. Basha CA, Selvi SJ, Ramasamy E, Chellammal S (2008) Chem Eng J 141:89-98

20. Dziubek J (2017) Web conf 17:1-8

21. Dambies L, Vincent T, Domard A, Guibal E (2001) Biomacromol 2:1454-1463

22. Gustafsson JP (2003) Chem Geol 200:105-115

23. Xu N, Christodoulatos C, Braida W (2006) Chemosphere 64:1325-1333

24. Koutsospyros A, Braida W, Christodoulatos C, Dermatas D, Strigul N (2006) J Hazard Mater 136:1-19

25. Rakshit S, Sallman B, Davantés A, Lefèvre G (2017) Chemosphere 168:685-691

26. Gecol H, Miakatsindila P, Ergican E, Hiibel SR (2006) Desalination 197:165-178

27. Rietra RP, Hiemstra T, van Riemsdijk WH (1999) Geochim Cosmochim Acta 63:3009-3015

28. Qian L, Zhang H (2011) J Chem Technol Biotechnol 86:172-184

29. Rahman I, Vejayakumaran P, Sipaut C, Ismail J, Chee C (2008) Ceram Int 2059:2066 
30. Di Renzo F, Valentin R, Boissiere M, Tourrette A, Sparapano G, Molvinger K (2005) ... Quignard F. Chem Mater 17:4693-4699

31. Robitzer M, Di Renzo F, Quignard F (2011) Microporous Mesoporous Mater 140:9-16

32. Klobes P, Meyer K, Munro RG (2006) In: Specific Surface Area and Pore Analysis by Gas Adsorption (ed), US Government printing office, Washington DC, p 23-24

33. Instruments $Q$ (2015) Powder Tech 51:51

34. Pawlak A, Mucha M (2003) Thermochim Acta 396:153-166

35. Fernandes Queiroz M, Teodosio Melo KR, Araujo Sabry D, Lanzi Sassaki G, Oliveira Rocha HA (2015) Mar Drugs 13:141-158

36. Tuchowska M, Muir B, Kowalik M, Socha RP, Bajda T (2019) Materials 12:2253

37. Guibal E, Milot C, Eterradossi O, Gauffier C, Domard A (1999) Int J Biol Macromol 24:49-59

38. Severo E, Rossi Abaide E, Gonçalves Anchieta C, Segabinazzi Foletto V, Trevisan Weber C, Bisognin Garlet T, Foletto E (2016) Mater Res 19:781-785

39. Bertoni FA, González JC, García SI, Sala LF, Bellú SE (2018) Carbohydr Polym 180:55-62

40. Das J, Sarkar P (2016) Environ Sci-Wat Res 2:693-704

41. Alekseev EV, Felbinger O, Wu S, Malcherek T, Depmeier W, Atuchin VV (2013) J Solid State Chem 204:59-63

42. Chiban M, Zerbet M, Carja G, Sinan F (2012) J Environ Chem Ecotoxicol 4:91-102

43. Taylor JB, Calvert D, Hun IR (1965) Can J Chem 43:3045-3051

44. Girma Asere T, Mincke S, Jeriffa DC, Verbeken K, Tessema D, Fufa F (2017) ... Du Laing G. Int J Environ Res Public Health 14:1-19

45. Pontoni L, Fabbricino M (2012) Carbohydr Res 356:86-92
46. Wan Ngah W, Fatinathan S (2008) Chem Eng J 143:62-72

47. Ayawei N, Ebelegi A, Wankasi D (2017) J Chem 2017:1-11

48. ZabihiSahebi A, Koushkbaghi S, Pishnamazi M, Askari A, Khosravi R, Irani M (2019) Int J Biol Macromol 140:1296-1304

49. Nisticò R, Celi LR, Bianco Prevot A, Carlos L, Magnacca G, Zanzo E, Martin M (2018) J Hazard Mater 342:260-269

50. Abou El-Reash YG, Otto M, Kenawy IM, Ouf AM (2011) Int J Biol Macromol 49:513-522

51. Ruiz M, Sastre A, Guibal E (2002) Sep Sci Technol 37:2143-2166

52. Chiou M, Li H (2003) Chemosphere 50:1095-1105

53. Tran HN, You SJ, Hosseini-Bandegharaei A, Chao HP (2017) Water Res 120:88-116

54. Qi J, Zhang G, Li H (2015) Bioresour Technol 193:243-249

55. Elwakeel KZ, Guibal E (2015) Carbohydr Polym 134:190-204

56. De Marques Neto JO, Bellato CR, Milagres JL, Pessoa KD, De Alvarenga ES (2013) J Braz Chem Soc 24:121-132

57. Gupta A, Chauhan V, Sankararamakrishnan N (2009) Water Res 43:3862-3870

58. Zeng H, Yu Y, Wang F, Zhang J, Li D (2020) Colloids Surf A 585:124036

59. Tajuddin Sikder M, Tanaka S, Saito T, Kurasaki M (2014) J Environ Chem Eng 2:370-376

60. He J, Bardelli F, Gehin A, Silvester E, Charlet L (2016) Water Res 101:1-9 